and $3 \%$ were from other ethnic groups. The pool is relatively balanced by gender. Firty-three percent of the students are women. GPA was not reported for all students, but for those whose GPAs were included a fifth had a 3.5 or better.

\section{Administration of the Project}

The process of identifying students for the Minority Identification Program begins with undergraduate advisors, who meet with promising minority undergraduates to discuss graduate study and professional careers in political science. The aim is to have personal contact with students to explain the opportunities and rewards of a career in political science and counsel them about programs that suit their particular interests.

After these meetings, the schools send names of students who indicate interest in participating in the Minority Identification Project to APSA. APSA in turn compiles a report on the students including their addresses, school, year of graduation, gender, ethnicity, GPA, and any additional information submitted about the student. This report, accompanied with mailing labels and, if requested, a floppy disk with the student data, is then sent to all participating graduate schools. (Only graduate schools who refer students from their undergraduate programs receive the student list.) Graduate schools then contact the students following their own recruiting practices.

Participating graduate schools also supply brochures about their graduate programs, which APSA collates and distributes to undergraduate advisors in the participating schools. The package of brochures is intended to be a resource for their department libraries and a tool for interesting minority students in graduate study.

Each student receives a letter from APSA to encourage them to consider graduate study and to let them know that the participating graduate schools have agreed to make extra efforts to provide funding to the minority students accepted to their programs. A copy of the APSA pamphlet, "Earning a Ph.D. in Political Science,"' which outlines admission procedures, how to choose a graduate program that matches students' interests, and where to seek financial aid is also sent to the students.

\section{Objective and Assessment}

The Minority Identification Project, which APSA plans to continue for ten years, is intended to broaden the composition of the political science profession. In its second year it has generated opportunities for graduate school minority recruitment and increased discussion about graduate study between minority undergraduates and their professors.

Success of the program depends on the quality of contacts between undergraduate faculty and students. When those conversations lead to an interest in graduate study and a career in the professoriate, the Minority Identification Project will assure that every opportuity exists to start a primising graduate career. All undergraduate programs are invited to submit names of promising students.

In the spring APSA will mail surveys to all of the students asking them to assess the project and report their decisions about graduate school. In addition, participating institutions will evaluate their own involvement in the program.

\section{Section News}

\section{Law, Courts and Judicial Process Section}

The Committee on the Pritchett Prize announced in the last issue of $P S$ is composed of David O'Brien, University of Virginia, Chair; Sheldon Goldman, University of Massachusetts, Amherst; Priscilla

Machado, U.S. Naval Academy. The committee solicits nominations for the best book in the last two years by a political scientist working in the field of law, courts and judicial process.

\section{Political Communication Section}

The Political Communication Section of the APSA announces a new award to be given at the 1991 APSA annual meeting for an outstanding paper in political communication.

The award will be made each year for the best paper in political communication delivered at the previous year's APSA annual meeting. It will be called the Ithiel de Sola Pool

Award in Political Communication.

Russell Neuman from the Massachusetts Institute of Technology will chair the nominating committee for 1991. Rod Hart from the University of Texas at Austin, and Susan Evans from the University of Southern California will also serve on this year's committee.

Now in its second year of existence, the Political Communication Section elected a new slate of officers. Doris Graber of the University of Illinois, Chicago, will chair the section. Other officers include Marion Just, vice-chair and chairelect, from Wellesley College; Ann Crigler, secretary-treasurer, from the University of Southern California; Bob Boynton, Program Chair, from the Universisty of Iowa; Ellen Mickiewicz, Chair of Nominations, from Emory University; and Robert Entman from Northwestern and David Paletz from Duke University, Members-at-Large.

The section publishes Political Communication Report three times annually. Each issue features original articles by political communication scholars, ranging across the broad spectrum of interests encompassed by the sub-field. In addition, the report includes recurrent feature articles on programs and curricula that focus on political communication. To enhance inquiry into political communication phenomena, the report also provides information about funding sources, projected and ongoing research, scholarly conferences, and similar matters. Currently a committee chaired by Bob Boynton from the University of Iowa and Jerry Manheim from George Washington University is considering ways to create new publishing opportunities for political communication research.

The section invites scholars interested in the sub-field of political communication to join.

\section{Political Organizations and Parties Section}

The Political Organizations and Parties Section recently elected its 


\section{Register now for the 1991 Annual Meeting}

Take advantage of our special low preregistration rates and register now for what promises to be the largest meeting to date. As past meeting attendees know, preregistration greatly facilitates receipt of your program, badge and badge cover at the meeting. And don't forget that those appearing on panels at the Annual Meeting must preregister by June 3, 1991 in order for their name to appear in the Final Program.

The 1991 APSA Meeting, which will be held from August 29 through September 1, 1991 in Washington, D.C. will focus on the theme "America as a Model for the World?", and will feature the traditional sections representing the major subfields of political science.

To register, fill out the form below and mail with your fee to: Annual Meeting Preregistration, The American Political Science Assn., $1527 \mathrm{New}$ Hampshire Avenue, N.W., Washington, D.C. 20036.

\section{Annual Meeting Preregistration Form}

$\square$...Regular Member

$\square$...Associate Member

$\square$...Student Member of APSA

$\square$...Non-member

Name

Address

Institutional

Affiliation (for badge)

$\square$ Credit Card: VISA or Mastercard

Card number:

$\$ 45$

$\$ 45$

$\$ 20$

$\$ 75$
Remittance MUST accompany this form. Return by August 1.

Signature:

Questions? Please call us at (202) 483-2512. 
new Executive Council. Serving for the next two years are Charles Barrilleaux of Florida State University, Joyce Gelb of City College of New York, Anne Hopkins of the University of Minnesota, and John S. Jackson III of Southern Illinois University.

The section plans on sponsoring two research agenda workshops in conjunction with the 1991 APSA annual meeting in Washington, D.C.

The first workshop is expected to be on studying local political parties and is planned for Wednesday before the meeting begins. This workshop involves presentations on substantive and methodological issues.

The other workshop is expected to be on studying interest groups and/or social movements. It is planned for Friday morning during two successive panel sessions. The Section welcomes suggestions for specific topics for this workshop.

Anyone interested in serving as a presenter for either workshop or who has suggestions for topics should call or write Ruth Jones, Department of Political Science, Arizona State University, Tempe, AZ 85287-2001.

\section{Representation and Electoral Systems Section}

Barbara Norrander of the University of Arizona was honored at the 1990 APSA annual meeting for the best paper presented at a panel sponsored by the Representation and Electoral Systems Section at the previous year's meeting. Her paper is entitled "Turnout in Super Tuesday Primaries: The Composition of the Electorate." The award includes a prize of $\$ 100.00$. Members of the Award Committee were Wilma Rule, John Phillips, and Dennis M. Anderson, Chair.

\section{State Politics and Policy Section}

The State Politics and Policy Section elected new officers at the APSA annual meeting. William Berry of Florida State University succeeded Virginia Gray of the University of Minnesota as President. Paul Brace of the University of Illinois, Chicago, was elected to replace David Lowery of the University of
North Carolina, Chapel Hill, as

Secretary-Treasurer.

Section members also elected Brace to edit the section Newsletter. Richard Winters of Dartmouth College, Ken Meier of the University of Wisconsin, Milwaukee, and Carol Weissert of Michigan State University were elected to fill three vacancies on the section's Executive Council.

The section invites scholars with interests in state politics to join. Those interested in receiving a copy of the section's newsletter contact Paul Brace, Institute of Government and Public Affairs, University of Illinois, 921 West Van Buren Street, Chicago, IL 60607. FAX: (312) 996-1404.

\section{Urban Politics Section}

Each year, the Urban Politics Section of the APSA makes an award for the best dissertation on urban politics or urban policy. Most of the nominations come from dissertation advisers and faculty members, but others may also make nominations. Please nominate outstanding dissertations in these fields to the Chairperson of the Best Dissertation Committee, Beverly Cigler, Public Administration and Policy, Pennsylvania State University at Harrisburg, Middletown, PA 17057; (717) 948-6050.

\section{REMINDER TO ALL NEW SECTIONS}

If you wish to join a section, and have already renewed your APSA membership, please send the appropriate amount for section dues to the APSA membership office. Organized Sections receive their allotment of section dues only after they have been paid to APSA. Early payment of dues is an important means of support for new Sections who are building their membership. Signing a petition to support formation of a section does not automatically make you a member. Section membership dues cannot be pro-rated, and must be renewed when you renew your APSA membership. You must be an APSA member to join a section.

\section{APSA 1991 Annual Meeting Destination: Washington, D.C.}

Once again APSA has planned an intellectually stimulating and informative Annual Meeting to be held August 29-September 1, 1991. Headquartered at the Washington Hilton and Towers in the heart of our nation's capital, it will focus on America as a model for the world. An impressively large number of panels and roundtables will contribute to this theme as well as ensure a diversified and exciting meeting.

The Washington, D.C. area will enhance the meeting experience by providing a variety of intellectual and cultural opportunities. The White House, the U.S. Capitol, Washington Monument, Vietnam Memorial, the historical Pavilion at the Old Post Office, beautiful Union Station, cultural Adams Morgan, and the numerous Smithsonian museums are just a few of the attractions to be enjoyed. In addition, during the evening Washington offers a plethora of fine dining, entertainment, and theatre-much of which is within walking distance from the Washington Hilton and Towers. Overall, the 1991 APSA Annual Meeting is one that you will not want to miss!

\section{Committee Named for Best Paper Award on Presidency}

In 1989 the Presidency Research Group initiated an award for the best paper on the presidency presented at the annual meeting of the American Political Science Association. The first award went to M. Stephen Weatherford of the University of California, Santa Barbara. PRG President James Sterling Young has recently announced the composition of the award committee for the 1990 award: Mark P. Petracca (chair), Margaret J. Wyzomirski, and Robert A. Strong. Nominations have been requested from each individual who chaired a PRG-sponsored panel at the 1990 APSA Meeting. In addition, the award committee is also open to nominations of papers on the presidency that may have been presented as part of other panels or sections. Nominated papers should deal with 